\title{
ARTICLES
}

\section{LIFE ASSURANCE AND CONSENSUAL DEATH: LAW MAKING FOR THE RATIONALLY SUICIDAL}

\author{
James Davey And John CogGon*
}

\section{Introduction: The Private/Public Law OverlaP}

DifFICUlT questions of medical ethics are often made more complex in the real world by the intrusion of private law considerations. The end of life choices of a mentally competent but terminally ill patient may be influenced by the consequences for the financial well being of surviving dependants. In particular, attention is likely to be given to the effect on any life insurance cover in place. For many this will represent the greatest financial asset contingent on death. There has been considerable debate as to the proper response of public law to these issues, in both the criminal and regulatory fields. However, the prosecutorial, judicial and jury discretions that bound these rules limit their impact in practice. By contrast, the private law principles that govern the distribution of assets on death have been largely overlooked. This article redresses that imbalance.

\section{A. Consensual Death and Life Assurance}

In the light of recent parliamentary debate on end-of-life decision making, ${ }^{1}$ as well as the continuing interest of commentators and the public, we consider in this article three methods of consensual death: suicide, mercy killing by a friend or relative (hereafter "mercy killing"), and physician-assisted death. Within the context of suicidal, terminally ill patients, the moral harm caused by any such consensual death may be equivalent, but there are differences in the legal consequences of each on life insurance policies. As a

* Cardiff Law School. The authors are grateful to Baroness Finlay of Llandaff and Professors Søren Holm and Phil Fennel of Cardiff Law School for their comments on an earlier draft. The usual caveat applies.

${ }^{1}$ E.g., the debate on end-of-life care, Hansard HC Deb vol. 436 cols. 365-385WH (19 July 2005). 
result, decision-making will be modified in ways that are considered unacceptable to members of all sides of the debate on assisted dying. $^{2}$ Our concern is that policymakers have failed to consider sufficiently the likely directive effect of legal rules on the financial considerations in end of life decisions. We will consider Lord Joffe's Assisted Dying for the Terminally Ill Bill 2005, but our argument has a broader application and relevance. Pressures for law reform in this area are continuous. The 2005 Bill fell at its second reading, but Lord Joffe immediately pledged to reintroduce it. ${ }^{3}$ During the lengthy parliamentary debate, there was no analysis of Clause 10 or economic pressures on death. ${ }^{4}$ It must be remembered that the recent Bill was a new draft of a proposal for legislation that has seen various incarnations. Even if it had been enacted, it would only have affected a relatively small class of individuals. ${ }^{5}$ This paper therefore looks at the real issue of financial considerations on end of life decision-making as a whole, and does not limit itself to legal instruments that only cover some cases.

\section{B. The Assisted Dying for the Terminally Ill Bill 2005/06}

The most recent version of the Assisted Dying for the Terminally Ill Bill $^{6}$ would have allowed physician-assisted suicide ${ }^{7}$ for competent adult patients $^{8}$ who suffer unbearably as a result of a terminal illness ${ }^{9}$ and have a prognosis of fewer than six months to live. ${ }^{10}$ The basis of the Bill was the principle of personal

${ }^{2}$ See Christian Medical Fellowship in Assisted Dying for the Terminally Ill Bill: Volume II Evidence (HL Paper 86-II, 2005), at p. 675: "Section [10] ... will also place huge pressure on patients to request early death in order that their families might benefit from insurance money ...". Cf., H. Biggs, "A Pretty Fine Line: Life Death, Autonomy and Letting it B" (2003) 11 Feminist Legal Studies 291, 298: "[H]ow can we be certain that a person is acting autonomously when she is clearly motivated by her perception of the needs of others?".

${ }^{3}$ See http://news.bbc.co.uk/1/hi/health/4763067.stm.

${ }^{4}$ See Hansard HL Deb. vol. 681 col. 1184 (12 May 2006).

${ }^{5}$ The issues concerning the legalisation of euthanasia and physician-assisted suicide have remained in the focus of public debate for some time and will continue to do so, despite the failure of Lord Joffe's Bill. The arguments for and against were previously considered in the Walton Report, Report of the House of Lords Select Committee on Medical Ethics (London 1994). Since then, legalisation of some form of medical killing has been seen in the Netherlands, Belgium, and Oregon. There was also a short-lived statute permitting euthanasia in the Northern Territory in Australia, and some forms of assisted suicide are permissible in Switzerland.

${ }^{6}$ The most recent version put before Parliament was the Assisted Dying for the Terminally Ill Bill (9/11/2005, HL), http://www.publications.parliament.uk/pa/ld200506/ldbills/036/ 2006036.pdf. Much of the parliamentary discussion to date centred on the 2004 version of the Bill, which was the subject of a Select Committee report. See http://www.parliament.uk/ parliamentary_committees/lordsassisted.cfm. Although the clauses of the earlier Bill were renumbered, there were no significant changes for the purposes of this article. References are to the 2005 Bill, unless stated otherwise.

7 Ibid., cl. 1 seemed to preclude the extension to active euthanasia.

8 Ibid., cls. 2(2)(b), 2(3)(b), 2(4), and 3.

9 Ibid., cls. 2(2)(d) and 2(3)(d).

10 "Terminal illness" was defined in ibid., cl. 13(1) as an inevitably progressive illness that may not be reversed by treatment, and will likely result in the patient's death within six months. 
autonomy. ${ }^{11}$ It is evident that this principle is understood in various ways, ${ }^{12}$ but the importance of a liberal conception of autonomy for competent adults is well established in medical law. ${ }^{13}$ The Bill would have extended the right to autonomy not only to patients, but also-via so-called conscience clauses-to medical practitioners ${ }^{14}$ and health care establishments such as hospitals and hospices. ${ }^{15}$ The Bill attempted to safeguard against covert killing and undue pressure being exerted on patients to opt for physicianassisted suicide both through provision of criminal offences ${ }^{16}$ and through a stringent formal process that must be fulfilled before a patient could "qualify" for assistance. ${ }^{17}$ A patient would have retained the right to revoke at any time his decision to die, ${ }^{18}$ and a "monitoring commission" would have reviewed each instance of physician-assisted suicide, referring cases to the Coroner if there were a two-thirds or unanimous opinion that the Bill had not been complied with. ${ }^{19}$ Apparently less controversial than these measures was clause 10, which sought to regulate the effect of physicianassisted suicide on life insurance.

Clause 10 of the Bill stated:

No policy of insurance which has been in force for 12 months as at the date of the patient's death shall be invalidated by reason of a doctor having assisted a qualifying patient to die in accordance with this Act.

It is this clause, with its consequences for the proceeds of life insurance policies in cases of physician-assisted deaths, that will provide the exemplar for much of this piece.

\section{Consensual Death: The Wider Context}

The broad debate on the appropriate reaction of the law to calls for legalising physician-assisted dying asks wider questions than those that would have been answered by the Bill. Necessarily, participants on all sides are drawn into consideration of factors that should be accounted or discounted when a person assesses the benefits and disbenefits of continued existence. The emergence and

11 See Assisted Dying for the Terminally Ill Bill (HL Paper 86-I, 2005), at p. 5, http:// www.parliament.uk/parliamentary_committees/lordsassisted.cfm.

12 Ibid., ch. 3.

${ }^{13}$ In Re T (Adult: Refusal of Treatment) [1993] Fam. 95; Ms. B v. An NHS Hospital Trust [2002] 2 All E.R. 449.

14 Assisted Dying for the Terminally Ill Bill, cl. 7(1).

15 Ibid., cl. 7(2).

16 Ibid., cl. 9.

17 Ibid., cls. 2, 4, and 5.

18 Ibid., cl. 6.

19 Ibid., cls. 11 and 12. 
increase of "death-tourism", 20 the perceived incoherence of the current, judicially developed, legal position, ${ }^{21}$ the suggestion that assisted dying already occurs on a large scale behind closed doors, ${ }^{22}$ and the tragic instances of family-members risking their own well being to help people in desperate conditions to die, ${ }^{23}$ all demand a detailed review of factors that modify people's end of life decisionmaking. Where coercive pressures are found to result from legal measures, there is a need for justification or alteration of the law.

Many factors will come into play when a person is considering ending his life. ${ }^{24}$ The law's effect varies depending on how the killing is to be performed. Suicide is no longer a criminal offence, ${ }^{25}$ although a person assisting a suicide can receive up to fourteen years' imprisonment. ${ }^{26}$ Within a medical context, the law draws a distinction between a competent adult's ${ }^{27}$ absolute right to refuse continued treatment, ${ }^{28}$ even when this will result in his death, ${ }^{29}$ and the extension of autonomous decision-making that would allow for positive, lethal intervention. ${ }^{30}$ Nevertheless, there is judicial acceptance that continued life is not always in a person's interests, ${ }^{31}$ and instances will certainly continue to arise where people seek a

${ }^{20}$ See M. Woolf, "Swiss Suicide Clinic Sees Number of British Clients Rise by 700 per cent". The Independent, 4 April 2005; M. Horsnell, "Woman Dies in Assisted Suicide after being Taken to Switzerland" The Times, 4 December 2004; M. Frith, "Kennedy Quits Euthanasia Society in Row Over Swiss Suicide Clinic" The Independent, 20 July 2004. As evidence of judicial reluctance to interfere, at least before the fact, see In re $Z$ (Local Authority: Duty) [2005] 1 W.L.R. 959.

21 J. Keown, "Restoring Moral and Intellectual Shape to the Law after Bland" (1997) 113 L.Q.R. 482; H. Biggs, "A Pretty Fine Line: Life Death, Autonomy and Letting it B" (2003) 11 Feminist Legal Studies 291.

22 H. Biggs, "The Assisted Dying for the Terminally Ill Bill 2004: Will English Law Soon Allow Patients the Choice to Die?" (2005) 12 European Journal of Health Law 43, 51.

23 J. Laurance and R. Verkaik, "Police Question Euthanasia Widow Over Husband's Death" The Independent, 22 January 2003; A. Norfolk, "Wife on Trial for Letting Husband Commit Suicide" The Times, 21 April 2005; D. Blamires, "Judge Frees 'Caring' Daughter who Aided her Mother's Suicide" The Independent, 30 June 1998; L. Peek, "Mercy for Husband who Killed Wife in Pain" The Times, 7 September 2002; J. Bale, "Former PC who Killed Dying Wife Spared Jail" The Times, 15 January 2005.

${ }^{24}$ J. Hardwig, "Is there a Duty to Die?" (1997) 27 Hastings Center Report 34.

${ }^{25}$ Suicide Act 1961 , s. 1.

${ }^{26}$ Ibid., s. 2(1).

27 A review of the case law suggests that the courts will not respect a child's suicidal refusal that is the result of metaphysical, superstitious, religious, or other abstract value-based reasoning: $\operatorname{Re} E$ [1993] 1 F.L.R. 386; Re $S$ [1994] 2 F.L.R. 1065; Re L [1998] 2 F.L.R. 810; Re $M$ [1999] 2 F.C.R. 577.

${ }^{28}$ In Re T (Adult: Refusal of Treatment) [1993] Fam. 95, “An adult patient who ... suffers from no mental incapacity has an absolute right to choose whether to consent to medical treatment, to refuse it or to choose one rather than another of the treatments being offered .... This right of choice is not limited to decisions which others might regard as sensible. It exists notwithstanding that the reasons for making the choice are rational, irrational, unknown or even non-existent ..." (per Lord Donaldson of Lymington M.R., at p. 102).

${ }^{29}$ Ms. B v. An NHS Hospital Trust [2002] 2 All E.R. 449.

30 Pretty v. United Kingdom (2002) 35 E.H.R.R. 1.

${ }^{31}$ NHS Trust v. Bland [1993] A.C. 789; In re J. (A Minor) (Wardship: Medical Treatment) [1991] Fam. 33; In re B (A Minor) (Wardship: Medical Treatment) [1981] 1 W.L.R. 1421; In re C (A Minor) (Wardship: Medical Treatment) [1990] Fam. 26; Re $R$ (Adult: Medical Treatment) [1996] 2 F.L.R. 99. See also In re Z (Local Authority: Duty) [2005] 1 W.L.R. 959. 
hastened death, either with the help of medical practitioners or of friends or relatives.

It is a reality that financial matters, including the financial consequences for others, will have an effect on a forming suicidal intent. We therefore look at the financial incentives and disincentives that the current legal frameworks create, and consider the function of clause 10. The clause has featured in previous drafts of the Bill, ${ }^{32}$ but has received little attention or scrutiny. We therefore have no reason to believe that it will not reappear in the future, Despite its apparent acceptability, we argue that it had only negative effects on the Bill. Because of the broader issues raised, but not addressed, by Lord Joffe's proposals, we extend our analysis to include the other forms of consensual killing listed above. For each of these, existing policy has the potential to affect the decisions of a rational, suicidal agent. An account is needed of the extent to which life insurance currently covers deliberate, consensual killings. By addressing this and associated questions of forfeiture, we better understand the significance of clause 10 . We place our analysis in a social and moral context, and consider the motivation for, and desirability of, such a policy. We suggest that these are matters for which Parliament should not legislate lightly, and regret the lack of attention that has been given to clause 10 in parliamentary debate and other scrutiny of the Bill.

\section{Consensual Death and Insurance Law}

In order to appreciate the economic implications of a consensual death, we need to understand the effect that each of the three types - suicide, mercy killings, and physician-assisted dying-would have on an otherwise valid insurance policy. If the legal rules provide greater resistance to one pathway than the others, then this is likely to affect the decision-making processes of the rational, suicidal being.

\section{A. The Nature of Life Insurance Cover}

Life insurance is not a single product, but a range of financial devices, with differing objectives. Of particular importance is the distinction between "whole life" and term insurance. In whole life cover, the insurer is bound to make a payment, as death is certain. The element of uncertainty on which the insurance is based is the unpredictability of the time of death. As premiums are normally paid on a periodic basis for the entire term of the contract, ${ }^{33}$ the

${ }^{32}$ Previously as cl. 12 .

${ }^{33}$ The amount of premium payable over time will vary, as may the eventual benefit. 
insurer estimates the number of such payments the insured will pay before dying, and prices the product accordingly. With term insurance, the underwriter is only obliged to pay if the death occurs within a specified time period. Commonly, at the end of the period, the surviving insured recovers nothing. ${ }^{34}$

Life insurance is normally offered as "all risks" cover. The claimant will have to prove the death of the life insured, but not the cause of death. This follows from the nature of all risks cover that the cause of death need not fall within a list of named causes, but will be covered unless excluded. The burden of proving an exception (whether express or implied) falls upon the insurer. Insurers may therefore expressly exclude liability for certain causes of death, for example, by reference to pre-existing conditions. The existence of express contractual limits on cover provides few doctrinal issues relevant to this discussion. Insurers are, at present, free to contract on whatever substantive terms they choose. This has not, traditionally, been an active area of regulation in the UK. ${ }^{35}$ However, the implied limitations, based on considerations of the nature of insurance, are more problematic. As Lord Sumner said of all risks cover in Gaunt:

[Insurance] covers a risk, not a certainty; it is something, which happens to the subject-matter from without, not the natural behaviour of that subject-matter, being what it is, in the circumstances under which it is carried. Nor is it a loss which the assured brings about by his own act, for then he has not merely exposed the goods to the chance of injury, he has injured them himself. Finally the description "all risks" does not alter the general law; only risks are covered which it is lawful to cover. ${ }^{36}$

This provides three limitations, which Lord Sumner considered to be generally applicable to all insurance policies:

(i) The cause must be something external to the subject matter of the insurance;

(ii) The cause must not be deliberately brought about by the insured's own act; and

(iii) The risk must be lawful to cover.

Together, the first two elements are fused into a concept of fortuity - what Lord Sumner described as the insurance of risks and not certainties. The final element is a statement of public policy, that insurance cannot be used in illegal ventures. The application of

\footnotetext{
${ }_{35}^{34}$ In some cases, a small return is provided, but not a full payment.

${ }^{35}$ Life insurance policies would be required to offer "cooling off" periods and the like, but the substance of cover is largely left to the market.

36 British and Foreign Marine Insurance Co. Ltd. v. Gaunt [1921] 2 A.C. 41, 57.
} 
these limits to contracts of life insurance, particularly in the context of consensual death, is problematic. For the mentally competent, the death will be deliberately brought about by the insured's act, or at least with his or her consent. In order to comprehend the novel insurance issues relating to physician-assisted deaths, we need to begin with areas that have been considered such as suicide and mercy killings.

\section{B. Life Insurance and Suicide}

The Office of National Statistics records the occurrence of suicide across the population. It remains a more likely cause of death for men than for women, and in particular for those aged between 15 and $44 .^{37}$ Given that a significant proportion of the population have life insurance, ${ }^{38}$ often to secure a mortgage, there is likely to be a considerable scope for overlap. Indeed, it is possible that those contemplating death will have made greater than average provision for their death, specifically to secure financial stability for their dependants. The extension of physician-assisted deaths would likely add to this number. Whilst estimates vary considerably, the chief proponent of the Bill suggested that around 650 deaths per year would result. ${ }^{39}$

\section{Suicide and Illegality}

Historically, the effect of suicide on a life policy was considerable. As sane suicide was a criminal offence until $1961,{ }^{40}$ the criminal act that caused death would bar recovery on the ex turpi causa rule of public policy. A clear example of this is found in Beresford v. Royal Insurance. ${ }^{41}$ The insured shot himself in 1934, almost 10 years after insuring his life, and minutes before the policy was due to expire. ${ }^{42}$ The insurance policy expressly excluded from coverage death by suicide within one year of the inception of the policy. However, the insurer sought to deny all liability for suicide, on the grounds that sane suicide was a criminal offence. The House of Lords confirmed that the loss was prima facie within the terms of the policy as the express contractual limit was inoperative. Lord Atkin stated that

${ }^{37}$ See A. Brock and C. Griffiths, "Trends in Suicide by Method in England and Wales, 1979 to 2001" (2003) 20 Health Statistics Quarterly 7.

${ }^{38}$ It is estimated that $50 \%$ of households have life insurance. See Office for National Statistics, UK 2005, (London 2004), at p. 466.

39 See Hansard HL Deb. vol. $674 \mathrm{col} .19$ (10 October 2005). Cp. the data for Orgeon's Death with Dignity Act with 171 reported cases in the first six years. See F. Pakes, "Under Siege: The Global Fate of Euthanasia and Assisted-Suicide Legislation" (2005) 13 European Journal of Crime, Criminal Law and Criminal Justice 119, 122. On the great potential for unreliability of extrapolated figures in this debate, see below Part III.

${ }^{40}$ Suicide Act 1961, s. 1.

${ }^{41}$ [1938] A.C. 586.

42 "Life Insurance and Suicide" (1937) 1 M.L.R. 154, 154. 
the underwriter would not normally be liable for losses caused by the insured's own deliberate act, as a matter of construction of the contract. He was clear that this was merely a default rule of interpretation: "on ordinary principles of insurance law an assured cannot by his own deliberate act cause the event upon which the insurance money is payable .... This is not the result of public policy, but of the correct construction of the contract". ${ }^{43}$ As a default rule this may be displaced by express terms of the contract, or by necessary implication. However, the court in Beresford refused to enforce the agreement on mandatory public policy grounds. As contractual performance was triggered by the commission of a criminal act, the court would not enforce the contract in favour of the deceased's estate. The personal bar to recovery was thereby extended on policy grounds to disentitle the deceased's estate (and thereby the testamentary beneficiaries). By contrast, commercial considerations meant that assignees for value would not be barred from recovery. Thus, the continuing use of life policies as security for loans would be unaffected, but the personal beneficiaries would be barred from recovery. Whilst suicide is no longer a criminal offence, the intervention of third parties in assisting suicide remains problematic. ${ }^{44}$

The history of suicide and life insurance shows the considerable civil law effect of criminalising certain pathways to consensual death. In so far as the mode of death is criminal, those who participate in the killing will normally be prevented from benefiting financially from the death. ${ }^{45}$ Whilst it may appear axiomatic, this bright line rule is as open to criticism as the suggestion that all killings are equally morally wrong. If we are to operate a linear scale for homicidal culpability, then the rule in Beresford is highly inconvenient. This is well demonstrated in the sphere of mercy killings, and is considered below in part C, Assisted Dying and Non-Physicians.

\section{Suicide and Fortuity}

The key implied exclusion for life insurance following the decriminalisation of suicide is that the underwriter is only obliged to pay where the death is a fortuity. Given that death will have been the intended consequence of the deceased's actions, this would appear to lack the fortuitousness required to constitute a risk

43 [1938] A.C. 586, 595.

44 Suicide Act 1961, section 2.

45 The one possible exception is in the inconsistent application of the forfeiture rule in cases of unlawful killing by the drivers of motor vehicles. See Dunbar v. Plant [1998] ch. 412, 435 per Phillips L.J: "Thus far, apart from in the motor cases, there has been no instance of the court failing to apply the forfeiture rule to a case of unlawful killing". 
capable of being covered by insurance. At first sight, this would fail the second of Lord Sumner's tests. The precise dividing line between risk and certainty therefore needs careful consideration in order to establish that suicide is indeed an insurable peril.

The difficulty to be faced is in reconciling the two different notions of fortuity given by Lord Sumner in Gaunt ${ }^{46}$ and Lord Atkin in Beresford. ${ }^{47}$ For Lord Sumner, the notion of risk is at the heart of insurance, and provides a mandatory rule. By contrast, Lord Atkin was much more relaxed about fortuity in the insurance of suicide, and classified it as merely a matter of contractual interpretation. The difference may be explained by judicial pragmatism. Faced with an established practice of insuring death by suicide, Lord Atkin refused to overturn contractual agreements merely because they did not fit within conventional categories of risk. ${ }^{48}$ By contrast, Lord Sumner was seeking to narrow cargo liabilities to commercially practicable levels. The differences may be explained by the public policy issues in each context.

Modern case law has identified, but not resolved, this conflict of approaches to fortuity. In The Wondrous, ${ }^{49}$ Hobhouse J. was faced with interpreting "loss of hire" and freight insurance contracts relating to a failed charterparty. The owners ${ }^{50}$ of the vessel had chartered it to an Iranian businessman for the carriage of molasses from Bander Abbas to European ports. The contract allowed for 40 days to load the molasses. However, due to the failure to pay local customs duties the harbour authorities detained the vessel for a period of 14 months. The question arose as to whether the delay was fortuitous. Hobhouse $J$. noted that the characterisation of fortuity was not straightforward. He noted that the detention of the vessel was not subjectively predictable at the moment the contract was agreed. However, he did not view this as determinative of the fortuity issue. He noted:

Where a situation comes about as a result of the voluntary conduct of the assured, it would not normally be described as fortuitous .... For the purposes of the law of insurance, in the absence of express agreement to the contrary, a policy should not be construed as covering the ordinary consequences of voluntary conduct of the assured arising out of the ordinary incidents of trading; it is not a risk. ${ }^{51}$

46 See note 36 above.

47 See note 43 above.

48 As noted above, Lord Atkin had no such difficulty in rejecting insurance of a sane suicide on the grounds of illegality - a stronger, mandatory rule.

49 Ikergi Compania Naviera SA v. Palmer, The Wondrous [1991] 1 Lloyd's Rep. 400.

50 Strictly speaking, the claimant was the bareback charterer of the Wondrous, but was treated by Hobhouse J. as the owner for these purposes.

51 Ikergi Compania Naviera SA v. Palmer, The Wondrous [1991] 1 Lloyd's Rep. 400, 416. 
This would suggest a two-stage test, requiring that the loss be both unexpected from the viewpoint of the assured at the moment of contracting and that it be not within the direct control of the assured. As such, consensual deaths would lack the required element of fortuity. However, if we follow The Wondrous, the doctrine is merely a rule of interpretation, and is displaced by contrary agreement. The decision in The Wondrous is unusual in that the non-fortuity defence has not been invoked on a consistent basis. This suggests that Lord Atkin's pragmatism has been favoured over the dogmatic approach of Lord Sumner. However, even Lord Sumner expressed the view that the level of proof required to satisfy his mandatory rule was not onerous. ${ }^{52}$

Given the inconsistent approach of the British courts, it is worth reviewing the academic literature. The precise nature of the doctrine of fortuity has been considered in detail in the US. ${ }^{53}$ Abraham suggests a wide conception of fortuity, to encompass situations where the loss is unexpected from the subjective viewpoint of the insured. ${ }^{54}$ Moreover, Abraham concludes that a loss only fails the test of fortuity if the insured knows of the near certainty of the loss at the moment of contracting, and not at the moment of loss. This is critical in answering the Sumner approach. ${ }^{55}$ The insured is protecting against a risk even if she brings about the event herself, providing she did not have that intention at the moment of contracting. In suicide cases, the insured is covering herself against the chance that she will form the intent to commit suicide during the term of the policy. Whilst the death by suicide may be a deliberate act, there is only a chance that this intent will arise, and that provides the element of uncertainty necessary for insurance.

In practice, this issue has been resolved by the introduction of a contractual exclusion for suicides occurring within a given period of time after the policy's inception. Such a term would be likely to be implied, even if not expressly provided in the policy. Life policies commonly provide for a minimum period of one or two years from the inception of the risk. It might be thought that such clauses reflect the need for the death to be fortuitous, but this is questionable. It is more likely that these clauses are designed to

52 British and Foreign Marine Insurance Co. Ltd. v. Gaunt [1921] 2 A.C. 41, 58 per Lord Sumner: "When he avers loss by some risk coming within 'all risks', as used in this policy, he need only give evidence reasonably showing that the loss was due to a casualty, not to a certainty or to inherent vice or to wear and tear. That is easily done".

${ }^{53}$ For a consideration of the notion of fortuity generally, see Notes "The Luck of the Law: Allusions to Fortuity in Legal Discourse" (1988-89) 102 Harv. L. Rev. 1862.

${ }^{54}$ See K. Abraham, "Peril and Fortuity in Property and Liability Insurance" (2000-2001) 36 Tort and Ins. L.J. 777, 792.

${ }^{55}$ For a contrary view, criticising the decline in the objective standard of fortuity, see S. Cozen and R. Bennett, "Fortuity: The Unnamed Exclusion" (1985) 20 Forum 222. 
reduce the adverse risk selection issues that would arise where a person purchases life insurance with the hidden intention of committing suicide. ${ }^{56}$ The hidden intention would not be included in the pricing of the risk, and so the cost of insuring the life would be subsidised. On that basis, the economically rational would overconsume, and purchase additional insurance at the subsidised rate. The effect would be to increase the cost of life insurance across the pool, as the subsidy for the undisclosed suicide risk would be met by the other members of the pool. This would, if unchecked, force out the low risk insureds, either to other providers or out of the market entirely.

The temporal restriction on suicide losses should not therefore be confused with any wider doctrine of fortuity. It ensures that the product can be accurately priced, and does not directly enforce public policy. As Abraham notes, ${ }^{57}$ what is objectionable about insuring known losses is not their lack of fortuity but their tendency to skew the relationship between the parties. Where the knowledge of the near-certainty of loss is mutual, there is no need for public policy to interfere.

In conclusion, whilst the conception of insurance as a device for the transfer of uncertain risks is often cited as an absolute rule, the precise limits of the doctrine appear to be vanishingly small. The judiciary are naturally disinclined to find that the express words of a policy are unenforceable, other than on clear public policy grounds such as criminality. ${ }^{58}$ The fortuity defence is therefore unconvincing as a justification for the inclusion of clause 10, and alternative explanations must be sought. We therefore return to the public policy illegality defence considered above, and the effect of this rule on other forms of assisted suicide.

\section{Assisted Dying and Non-Physicians}

Where mentally competent but terminally ill patients are unable or unwilling to commit suicide, they may seek assistance from a friend or relative. The difficulties that this causes are evident. Not only does the third party risk criminal sanction, ${ }^{59}$ but also the loss of any testamentary benefits, including life assurance monies. This

${ }^{56}$ Insurance law requires that the insured disclose all circumstances material to the risk prior to contracting. However, the underwriter would have to prove non-disclosure in order to avoid the contract. The one-year exclusion avoids the need to prove non-disclosure.

${ }^{57}$ K. Abraham, "Peril and Fortuity in Property and Liability Insurance" (2000-2001) 36 Tort and Ins. L.J. 777, 802.

58 See further the willingness of the courts to limit the boundaries of similar definitional elements of insurance such as insurable interest and indemnity.

59 The person assisting the death may be open to a charge of the common law offence of murder, one of the forms of voluntary manslaughter under the Homicide Act 1957, or aiding, abetting, counselling, or procuring another's suicide under the Suicide Act 1961, s. 2. 
arises through the application of the ex turpi causa rule considered above. However, the application of the general principle has been modified somewhat by the Forfeiture Act 1982. Under this, the court is granted discretion to disapply the forfeiture rule (in whole or in part) in favour of persons who have unlawfully killed another. ${ }^{60}$ The decision whether or not an unlawful killing has occurred is in the hands of the civil court deciding on the application, and is not normally dependent on a conviction of any specific offence in a criminal case. However, the discretion cannot be exercised in favour of persons convicted of murder. ${ }^{61}$ This provides a wide-ranging exception to the forfeiture rule and can be used by those convicted of manslaughter, and of aiding, abetting, counselling or procuring a death. ${ }^{62}$ The prosecutorial decision as to which charge to bring is therefore crucial. It is well established that the class of offences treated in law as murder includes a range of situations generally considered less culpable than certain types of manslaughter. ${ }^{63}$ The partner who smothers a terminally ill companion risks a mandatory life sentence and a prohibition on testamentary benefits. By contrast, if the charge is one of manslaughter, there is the chance of avoiding a custodial sentence and applying for financial assistance under the Forfeiture Act.

An examination of the exercise of the prosecutorial discretion reveals a level of unpredictability regarding which charge is brought. Smothering a person with a pillow, for example, may attract a charge of murder or assisted suicide ${ }^{64}$ or manslaughter. ${ }^{65}$ Furthermore, juries in criminal trials may be reluctant to find a murder has been committed in circumstances where the defendant has committed an act that may be morally mitigated. ${ }^{66}$ Judges may vary their understanding of legal concepts, such as intention, in order to achieve a morally preferable outcome, whilst ostensibly applying objective legal norms. ${ }^{67}$ There is judicial and academic

${ }^{60}$ Forfeiture Act 1982, s. 2.

${ }^{61}$ Forfeiture Act 1982, s. 5. See Davitt v. Titcumb [1990] ch. 110.

62 Forfeiture Act 1982, s. 1(2).

${ }^{63}$ See R. v. Howe [1987] 1 A.C. 417, 433, per Lord Hailsham: "Murder, as every practitioner of the law knows, though often described as [a crime] of the utmost heinousness, is not in fact necessarily so, but consists in a whole bundle of offences of vastly differing degrees of culpability, ranging from brutal, cynical and repeated offences like the so called Moors murders to the almost venial, if objectively immoral, "mercy killing' of a beloved partner".

${ }^{64}$ D. Blamires, "Judge Frees 'Caring' Daughter who Aided her Mother's Suicide" The Independent, 30 June 1998.

${ }^{65}$ L. Peek, "Mercy for Husband who Killed Wife in Pain" The Times, 7 September 2002.

${ }^{66}$ See Gray v. Barr [1971] 2 Q.B. 554, 581 per Salmon L.J: "Manslaughter is a crime which varies infinitely in its seriousness. It may come very near to murder or amount to little more than inadvertence, although in the latter class of case the jury only rarely convicts" (emphasis added). See further the careful summing up of Ognall $\mathrm{J}$. to the jury in the case of $R$. v. Cox (1992) 12 B.M.L.R. 38, although note that in this case the charge was one of attempted murder.

${ }^{67}$ A. Norrie, “After Woollin” [1999] Criminal Law Review 532. 
opinion in support of the apparently all-encompassing existing law because of the flexibility that the prosecutorial discretion actually affords defendants. ${ }^{68}$ The likelihood of avoiding the harshest criminal sanctions notwithstanding, the punitive or directive effect of financial considerations may still come into play. In the case of Gray v. Barr ${ }^{69}$ the Court of Appeal refused to accept that a civil court could be restricted by the finding of "not guilty" in a criminal trial for murder. As Lord Denning M.R. stated: "[t]here is no doubt, to my mind, that Mr. Barr was guilty of manslaughter. I know that at the criminal trial he was acquitted altogether. But that was a merciful verdict: and in this civil action we must, when called upon, give the true decision according to law". ${ }^{70}$

This approach was confirmed in the leading case on the application of the Forfeiture Act 1982, Dunbar v. Plant. ${ }^{71}$ This concerned a suicide pact made by a young couple, Tony Dunbar and Nanette Plant. Plant was accused of theft at her workplace and decided to commit suicide. Her partner decided that he could not live without her. They attempted, unsuccessfully, to kill themselves by carbon monoxide poisoning. They then tried to hang themselves with cable, but this also failed. In the final joint attempt, to hang themselves with bed sheets, Dunbar was killed but Plant survived. After the event, Plant attempted suicide on several further occasions, but survived each time. No criminal proceedings were brought against her. Despite this, the Court of Appeal confirmed the finding of the trial judge that, "... on applying the civil burden of proof ... Miss Plant had committed an offence ... namely that of aiding, abetting, counselling or procuring his suicide contrary to section 2(1) of the Act of 1961". ${ }^{72}$

Following Dunbar v. Plant, even where the prosecutorial decision is that no charge needs to be brought, private law consequences remain a very real possibility. Sympathetic family members may be assured that they are unlikely to be convicted of an unlawful killing that they have, strictly speaking, committed. ${ }^{73}$

${ }^{68}$ Lord Hailsham in R. v. Howe [1987] 1 A.C. 417, at p. 433; Lord Simon in DPP for Northern Ireland v. Lynch [1975] A.C. 653, at p. 687; Y. Kamisar, "Physician-Assisted Suicide: The Problems Presented by the Compelling, Heartwrenching Case" (1998) 88 J. Crim. Law Criminol. 1121; B. Steinbock, "The Case for Physician-Assisted Suicide: Not (Yet) Proven" (2005) 31 Journal of Medical Ethics 235.

69 [1971] 2 Q.B. 554.

${ }^{70}$ Gray v. Barr [1971] 2 Q.B. 554, 567-568 per Lord Denning M.R.

${ }^{71}$ [1998] ch. 412.

72 Ibid., p. 419.

73 This does not, of course, mean that the patient will wish to expose such family members to the risk of prosecution: see H. Smith and R. Smith, "Doctors Cannot Simultaneously be Patient Centred and Reject Assisted Suicide (Letter)" (2005) 331 B.M.J. 842-843, "If I feel dementia approaching, I could of course kill myself. There's nothing illegal about that, but I would be reluctant to involve my family and friends - for fear that they might be implicated in doing something illegal". 
However, there is no guarantee that a life insurer will have to pay out to the beneficiary of a policy if he has assisted in causing the death.

The Court of Appeal in Dunbar v. Plant went on to give a considered view on the application of the forfeiture rule to such potentially morally mitigated unlawful killings as suicide pacts. This may be instructive for similarly complex cases such as mercy killings. Mummery L.J. noted that the rule was not simply there to deter killing for profit. He cited with approval Australian authority to the effect that "the rule does not rest on a disapproval of greed". ${ }^{74}$ On this basis, even suicide pacts attracted the operation of the forfeiture rule. Phillips L.J. confirmed the application of the common law forfeiture doctrine to survivors of suicide pacts, even though he recognised:

[A] suicide pact may be rational, as where an elderly couple who are both suffering from incurable diseases decide to end their lives together or it may be the product of irrational depression or desperation. In neither case does it seem to me that the public interest will normally call for either prosecution or forfeiture should one party to the pact survive. ${ }^{75}$

On this basis, Phillips L.J. (with whom Hirst L.J. agreed) held that the appropriate manner in which to exercise the discretion afforded by the Forfeiture Act was to grant Plant full relief against the rule. This is indicative of the probable approach to be taken in mercy killings, where similar mitigating factors are likely to exist. Indeed, given the empathy demonstrated with the elderly couple wishing to die together in his example, it is hard to see how Phillips L.J. could support any decision other than full relief where a family member benevolently assists in the suicide of a loved one. However, it will be remembered that where the claimant is convicted of murder, the court has no discretion to disapply the forfeiture rule. This has the unfortunate consequence of preventing dependants of the murderer from recovering through him, even when it is likely that the intention of the deceased would have been to provide for those relations. In the case of $\operatorname{Re} D W S$ (deceased), ${ }^{76}$ both parents were murdered by their son. Neither parent had left a will. The effect of the forfeiture rule was to bar their killer from recovery under the intestacy. Whilst this result was unobjectionable in itself, it also barred the killer's son (the deceased persons' grandchild) from recovery. On this basis, the assets were distributed to more remote relatives of the murdered couple. Whilst the murders in $\operatorname{Re} D W S$

\footnotetext{
${ }^{74}$ [1998] ch. 412, 425 citing Troja v. Troja (1994) 33 N.S.W.L.R. 269, 299 per Meagher JA.

75 Ibid., at p. 438

76 [2001] ch. 568.
} 
were not consensual, a similar situation could arise in the context we are considering here. A simple example will suffice. Assume a mentally competent but physically disabled person. Wishing to die, she requests that her husband kill her. He obtains and administers a lethal dose of drugs. If convicted of murder, then following $R e$ $D W S$ not only the husband but also the children would be barred from recovering through their father from the mother's estate on intestacy. The Law Commission has recently suggested that the rule in $R e D W S$ be overturned, by the adoption of the legal fiction that the murderer pre-deceased the victims. ${ }^{77}$ This would allow those dependent on the murderer to recover, but not the convicted person directly.

There is evidence of a trend away from applying the full rigour of the public policy rules to "morally mitigated" unlawful killings. However, the ability of the judiciary to do this is still limited by the restrictions found within the Forfeiture Act 1982. Nevertheless, there does appear to be a genuine sensitivity evident in the judgments of Phillips and Mummery L.JJ. in Dunbar v. Plant and this is to be applauded.

It is worth pausing for a moment to consider the rules reviewed to date. The two obvious bars to recovery on an insurance policy tied to a physician-assisted suicide are, at present, the ex turpi causa forfeiture rule or, alternatively, a lack of fortuity. However, neither presents an absolute bar to recovery. The fortuity rule appears much more limited in practice than is suggested by some judges. Moreover, the forfeiture rule is limited by statutory intervention, and will have no application if physician-assisted suicide is decriminalised. ${ }^{78}$ Having considered the established private law consequences of suicide and mercy killings, we now turn to the statutory efforts of Lord Joffe in seeking the legitimisation of physician-assisted suicide, and in particular the impact of Clause 10.

\section{Physician-Assisted Suicide}

It is not assumed that the text of any future Assisted Dying for the Terminally Ill Bill will strictly follow that of its predecessors. Indeed, Deborah Annetts of the Voluntary Euthanasia Society, ${ }^{79}$ who has worked closely with Lord Joffe on the Bills, said that she anticipated further changes to the 2005 Bill prior to its presentation

77 Law Commission Report No. 295 The Forfeiture Rule and the Right of Succession (Cm. 625, 2005), at [1.15].

${ }^{78}$ In any event, only those considered guilty of a criminal offence (even if by a civil tribunal) would be subject to the forfeiture rule. For a physician-assisted suicide, that medic would be barred from recovery, but not other testamentary beneficiaries.

79 Now renamed "Dignity in Dying". 
to Parliament. ${ }^{80}$ Any later version is likely to undergo a similar process of revision. In its most recent form, the Bill proposed to provide the option of medically assisted suicide ${ }^{81}$ for competent adults who have an illness that will kill them within six months, and who suffer unbearably as a result of their illness. ${ }^{82}$ The Bill contained provisions that are intended to act as a safeguard against abuse. Abuse seems here to mean either that a person is covertly killed against his will, or that he is put under unacceptable pressure to form a suicidal intent. A previous version of the Bill failed for want of Parliamentary time, having been the subject of a report by a House of Lords Select Committee. ${ }^{83}$ Among the Committee's recommendations were the suggestions that the report be debated in the House, and that if a similar Bill were to be introduced that it be examined by a Committee of the whole House. ${ }^{84}$

The regulatory approaches discussed above in respect of suicide and other assisted suicides provide models for physician-assisted suicide. That mode of deliberate killing would have been decriminalised, in common with suicide generally. However, the intervention of a third party provides commonality with mercy killings. It is therefore useful to consider the function of clause 10 of the 2005 Bill. This has to be inferred, as the Select Committee report on the prior Bill fails to describe the effect of clause 12 (as it then was), even in the section marked "The Bill in More Detail". ${ }^{85}$ The discussion skipped from clause 11 to clause 13 without comment. Similarly, Lord Joffe's own evidence to the House of Lords Select Committee merely repeated the provision without comment or explanation. ${ }^{86}$

Without the proposed legislative intervention, insurers would generally be liable, as life assurance is normally offered on an "all risks" basis. Insurers would remain free expressly to exclude coverage for deaths by assisted suicide. However, given current market practice is to cover suicide, the widespread use of such an exclusion is unlikely.

Suggestions that the loss would not be recoverable because the moment of death was chosen by the insured are unlikely to

${ }^{80}$ Paper presented at the International Symposium on European perspectives on end of life decision-making (14-15 September 2005), see http://www.imlab.ac.uk/endoflife.htm.

81 Assisted Dying for the Terminally Ill Bill 2005, clause 1 seems to preclude active voluntary euthanasia.

82 Ibid., cl. 2.

83 Assisted Dying for the Terminally Ill Bill (HL Paper 86-I, 2005). See http://www.parliament.uk/ parliamentary_committees/lordsassisted.cfm.

84 The first recommendation was followed, the second was not.

${ }^{85}$ Assisted Dying for the Terminally Ill Bill (HL Paper 86-I, 2005), at [33]-[34]. See http:// www.parliament.uk/parliamentary_committees/lordsassisted.cfm.

${ }^{86}$ Assisted Dying for the Terminally Ill Bill: Volume II Evidence (HL Paper 86-II, 2005), at p. 50 . 
succeed. As noted above, the fortuity defence was not successful in defeating insurance coverage for suicide. Moreover, if Abraham is correct and the fortuity rule acts as a proxy for concerns that the insured may have a "hidden intention" to bring about the risk once covered, there is no credible risk in physician-assisted suicides anyway. We would have to imagine that the insured had a terminal illness that is known to him but that he failed to disclose. In order to have fallen within Lord Joffe's Bill, the patient must have had a prognosis of only six months to live when the request for assistance is made. Under English insurance law, insurers would have a right to avoid the contract if any material facts were withheld at the time of contracting, and would only need to raise the fortuity defence if they could not show that this was a circumstance material to the risk and that it would have affected its underwriting decision. ${ }^{87}$ This seems unlikely in practice. Moreover, insurers commonly require access to medical records. We have to imagine a condition known to the patient (but not to his doctor) at the time of buying the policy, which is sufficiently manifested during the term of the policy to give a prognosis of less than six months to live. Given the disclosure requirements, it is difficult to imagine a commercial judge viewing such losses as so significant that a fortuity defence need be constructed to control them. If insurers are told of the condition before contracting, then there is no need to interfere. They will not insure the terminally ill at normal rates, if at all. Returning to the suicide cases for a moment, if Mr. Beresford's death in the taxi were seen as insurable, even with a doctrine of fortuity, it seems unlikely that a physician-assisted suicide would be characterised differently.

In any event, clause 10 did not expressly deal with this issue. It stated that the policy shall not be invalidated by the intervention of the physician. This wording is not ideal. As noted above, the fortuity defence is not generally considered to invalidate the policy, but serves as a rule of construction. Thus, non-fortuitous losses do not bring the contract to an end (or otherwise invalidate the agreement) but merely do not fall within the terms of the agreement.

Even if we approve of the likely intention of clause 10, to support those who wish to seek physician-assisted death, there are numerous ways in which an insurer could simply have contracted around the Bill. First, we know that those likely to seek to use the Bill will do so because they suffer from a reasonably predictable range of terminal conditions. An insurer could simply contract out

${ }^{87}$ The disclosure rules are exemplified by the Marine Insurance Act 1906, s. 18 . 
of liability for death caused by these conditions. This would worsen the overall position of such patients, in comparison to the status quo. Secondly, the contract could provide that in the event of a physician-assisted death the payout is reduced to $£ 1$. This does not invalidate cover, as life insurance is not seen as an indemnity ${ }^{88}$ and it is for the parties to set whatever figure they desire for the value of a life in any given circumstance. This is not invalidating cover, merely reducing it. We could go on, but it is pointless to do so. Clause 10 is badly drafted. As a symbol of moral reassurance, ${ }^{89}$ it may be of utility, but as a piece of legislation it is worse than useless.

What clause 10 appears to do is to remove the insurance industry's option to exclude liability for physician-assisted suicides. Piecemeal reform of this type often leads to inconsistent results. It is not clear why insurers would remain free to exclude liability for suicide but not physician-assisted suicide. Indeed, this restriction on the freedom to contract as insurers see fit is alarming. Lord Joffe's Bill was designed to ensure freedom of conscience to those involved in the death, including the patient, the doctors, and the witnesses to the patient's declaration. However, insurers will not be free to take an ethical stance. Within the US there are a number of insurance providers who operate on the basis of Catholic principles. ${ }^{90}$ The leading British specialist "religious" insurer, Ecclesiastical Insurance, supports the Church of England website that is actively campaigning against the decriminalisation of assisted suicide. ${ }^{91}$ Moreover, Ecclesiastical Insurance has a captive charity whose purposes include the promotion of the Christian religion. ${ }^{92} \mathrm{~A}$ refusal by this or any other insurer to extend life cover to physician-assisted suicides would have been prohibited under Lord Joffe's Bill. Even if we do not believe in "freedom of conscience" for legal persons such as insurers, the market access issue remains. If there is a niche market for life assurance that does not extend to death by suicide, physician-assisted or otherwise, then why should such consumers be denied? Providing there is a competitive market for insurance, market interference should be kept to a minimum. At present, no one has explained why the deleterious effects of clause 10 should be ignored. This was an ill thought-out response

\footnotetext{
${ }^{88}$ For an extreme example of this, see Fuji Finance Inc. v. Aetna Life Insurance Co. Ltd. [1995] ch. 122.

${ }^{89}$ See text to note 97 below.

${ }^{90}$ See http://www.cfli.org and http://www.catholiclifeinsurance.com. Within the UK, most current mutual insurers operate on a secular basis, but many have ethical investment policies. See UIA at http://www.uia.co.uk (an ethical investment fund) and the "Sons of Temperance" at http://sonsoftemperance.co.uk (on a tee-total basis).

${ }^{91}$ See http://www.cofe.anglican.org/info/euthanasia.

92 See http://www.ecclesiastical.co.uk.
} 
to a problem that probably never would have arisen in practice anyway. If most insurers cover suicide, then why would they exclude physician-assisted suicide? The silence from the proponents of the Bill on this point is deeply regrettable.

Moreover, it is worth considering whether insurers might justifiably wish to exclude assisted death for certain types of insurance. If we assume that the right to assist suicides remains restricted to those who are terminally ill, and with only six months to live, the only substantial cost for whole life policies is the lost premiums for the period by which death is accelerated and the lost time value of money. ${ }^{93}$ These costs can be readily absorbed by the insurer as there will only be a limited number of insured persons who will be able to take advantage of the new provisions and the cost for each will be low. ${ }^{94}$ However, of greater significance is the effect on the term insurance market. Where the insurance payment is contingent on death occurring within a set period of time, acceleration of the time of death may be critical. Where the natural death would fall outside the period of insurance, a physicianassisted suicide would convert an uncovered loss to a covered one. This represents a shift in the actuarial patterns of losses. If the number of assisted suicides remains low, this may not affect the market. Not many persons will have a life insurance policy expiring within a few months, and a prognosis of less than six months to live. However, the pressure to die quickly to release life insurance monies was noted in evidence to the Select Committee. ${ }^{95}$ If we object to the possibility that even a single person may be pressured into dying quickly because of the existence of his life insurance, then we would simply have to remove either the money or those exerting pressure from the decision-making process. If we adopt a more pragmatic approach, we will hope that a mentally competent individual will merely view the insurance money as a factor in the decision, and not be pressurised. The Bill did take care to avoid obvious moral hazard issues by proposing that the witnesses be independent of the patient. On that basis, relatives and partners are excluded. The risk of financial factors affecting the judgment of the witnesses is also controlled by clause $8(5)$, which proposes

${ }^{93}$ See F. Parker, H. Rubin and W. Winslade, "Life Insurance, Living Benefits and Physicianassisted Death" (2004) 22 Behav. Sci. Law 615, 619.

${ }^{94}$ See discussion to note 39 above.

95 The Disability Rights Commission noted in its evidence an example given by Baroness Finlay relating to a patient whose relatives had pressed for increased doses of diamorphine with the presumed motivation of ensuring an accelerated death so as to trigger a term policy before it expired. See Assisted Dying for the Terminally Ill Bill: Volume II Evidence (HL Paper 86-II, 2005), at p. 224. 
... nor may any person act as a witness, if he has grounds for believing that he will benefit financially or in any other way as the result of the death of that patient.

Whatever the ethical dimension, the statutory removal of the option to exclude such losses seems an unjustifiable interference in the operation of the market. If regulation is to be implemented, it would be preferable for a soft law model to be adopted. This could take the form of guidelines negotiated with the insurance industry, and reviewed periodically, as with the insurance industry's use of genetic information.

We have considered above the private law principles that surround end-of-life decisions. The next step is to place this in a wider ethical context. It is clear that how we choose to die affects, and will continue to affect, how our assets are passed on. The following section considers the appropriateness of this result.

\section{Life InSurance AND END of Life Decisions: Towards AN Objective Framework for Consensual Death}

It is important to consider two fundamental questions here: first, whether it is right to treat differently cases of suicide, mercy killing, and physician-assisted death; and second whether policy-makers or insurers should have a role in limiting the factors that go into a person's suicidal decision. We have shown that clause 10 of Lord Joffe's Bill was not necessary: the decriminalisation of suicide marked the end of a defence for insurers. The feared significance and implications of its absence are unfounded. Its presence, however, did not represent a mere harmless superfluity. Although a full answer is beyond the scope of this paper, it is necessary to ask what might have motivated the drafters of the Bill to include clause 10 at all. It may simply have been lifted from Oregon's Death With Dignity Act, which provides much more detailed restrictions on what can form part of a suicidal patient's motivations:

ORS $127.870 \$ 3.12$. Effect on construction of wills, contracts and statutes.

(1) No provision in a contract, will or other agreement, whether written or oral, to the extent the provision would affect whether a person may make or rescind a request for medication to end his or her life in a humane and dignified manner, shall be valid.

(2) No obligation owing under any currently existing contract shall be conditioned or affected by the making or rescinding of a request, by a person, for medication to end his or her life in a humane and dignified manner. 
$127.875 \S 3.13$. Insurance or annuity policies.

The sale, procurement, or issuance of any life, health, or accident insurance or annuity policy or the rate charged for any policy shall not be conditioned upon or affected by the making or rescinding of a request, by a person, for medication to end his or her life in a humane and dignified manner. Neither shall a qualified patient's act of ingesting medication to end his or her life in a humane and dignified manner have an effect upon a life, health, or accident insurance or annuity policy.

$127.880 \$ 3.14$. Construction of Act

Nothing in ORS 127.800 to 127.897 shall be construed to authorise a physician or any other person to end a patient's life by lethal injection, mercy killing or active euthanasia. Actions taken in accordance with ORS 127.800 to 127.897 shall not, for any purpose, constitute suicide, assisted suicide, mercy killing or homicide, under the law.

The drafters of Lord Joffe's Bill may have considered that there would be a need for a similar provision in the UK, without fully understanding the existing legal position. In contrast with the UK Bill, the Oregon Act does not require a patient's suicidal intent to stem from unbearable suffering caused by his terminal illness, although such an illness must inhere in the patient. Use of the Oregon Act is limited to people whose decision is "based on an appreciation of the relevant facts", 96 some of which the legislator has defined for itself. The decision to remove influencing factors that are within the State's control provides a tacit acknowledgement of the potential directive effect of such factors. However, the need for clause 10 in the UK does not necessarily follow. It stood in isolation, unlike the similar provision in Oregon. This is likely because the Assisted Dying for the Terminally Ill Bill elsewhere restricted the valid reason for a suicidal intent (i.e., to unbearable suffering as a result of a terminal illness). But even if there were a good reason only for worrying about the coercive effect of contracts that are for life insurance, the existing law rendered clause 10 unnecessary.

Alternatively, the reasoning for including clause 10 may be coupled with that which led to the insertion of clause $8(4)$ of the Assisted Dying for the Terminally Ill Bill. This said that a physician who assists a death conforming to the requirements of the Bill "shall be deemed not to be in breach of any professional oath or affirmation". The Bill was premised on an understanding of individual autonomy; on allowing society to respect each competent adult's moral choice. However, clause 8(4) arguably went beyond a

${ }^{96}$ The Oregon Death With Dignity Act 127.800 , s. 1.01(7). 
system designed to accommodate some breed of moral relativism by purporting to proclaim the moral neutrality, or even rightness, of assisted suicide, rather than moral indifference towards it. If this line of reasoning is accepted, it might be suggested that clause 10 really served as a moral reassurance to those contemplating suicide under the Bill's terms. ${ }^{97}$ It thereby denied the possibility for life insurers to have an ethical policy reflecting disapprobation of physician-assisted suicide. We have seen no justification advanced for allowing freedom of conscience to patients, to physicians, ${ }^{98}$ and to health-care providers, ${ }^{99}$ but not to insurers.

\section{A. The Need for Debate}

The three forms of self-destruction that we consider in this paper ${ }^{100}$ all relate to the competent decision-making of adults. This is an area where little broad consensus can be found on many of the issues. Many who accept the validity of arguments in favour of euthanasia or physician-assisted suicide would seek to limit the pressures that would be permissibly accounted for in coming to a decision to end life. ${ }^{101}$ Even those whose arguments rest solely on a conception of autonomy ${ }^{102}$ - in other words, who do not attribute, for example, pain, suffering, or ill health as necessary components of a rational suicide - would limit external factors that might bear on the autonomy of the decision-maker. As for those who are opposed to the killing of innocents, it is imaginable that they could distinguish between better and worse reasons for doing it. ${ }^{103}$ For example, the voluntary desire to die of a person suffering intractable and excruciating pain might at least attract some sympathy whilst still not being condoned, rendering a desire driven by treatable or avoidable suffering to be considered more wrong.

Moral "duty to die" arguments have developed under various guises. Within the context of the family, Hardwig argues that a duty to die exists in some circumstances because of responsibilities held by the patient to his family that, on balance, outweigh their responsibilities to keep him alive. ${ }^{104}$ At a wider, societal level, where people compete for scarce resources, it has been argued that there may be a duty on some people to die. ${ }^{105}$ We do not seek to argue

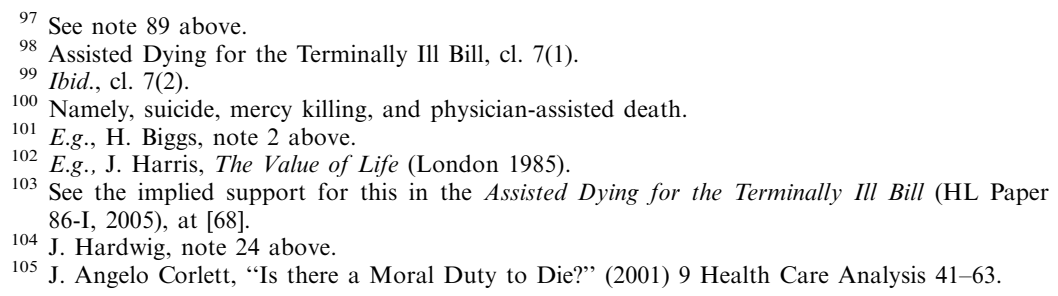


here in favour of a duty to die, in either a moral or a legal context. The utility of Hardwig's theory within moral philosophy has been questioned, ${ }^{106}$ but the points he makes are useful to the current analysis. It is not really relevant whether a person's ethical decisions are based on a universally applicable, deontological theory, a breed of utilitarianism, or an inconsistent and unarticulated mess of ideals. None of us is required by law to adopt, let alone be able to describe, a specific moral framework. What Hardwig recognises is that individualism is not the key to our decisions. The notion of a duty to die has such emotive capacity that it may be cited as something that of itself is wrong without the need for explanation. But much of what Hardwig says is not controversial. His assertions that our interests are in part defined by the interests of those we are close to must be right. There may be some people capable of unadulterated selfadvancement, but the majority will surely consider the well being of their families as part of an assessment of their own well being. And included in the assessment will be financial well being.

Money is something of a metaphor. ${ }^{107}$ This is what allows it to assist rhetoricians, who can use it to imply that claims of financial constraints should not be invoked because of life's incommensurability. Such arguments should be resisted: reality demands that economic considerations be made. What money represents is a means of prioritising, and an order of priorities may be open to valid criticism. It is not simple enough, however, to state that money is itself wrongly brought into an equation. Perhaps the rhetoric is inevitable, and that is probably why Hardwig posits the decisions as being ones between a short amount of extra life balanced against a career or a place in college or a happy retirement, rather than stopping after a simple statement regarding financial considerations. If that is a necessary qualification or explanation, so be it. But it is important to note that we would be irresponsible to set aside the questions raised here just because they ask for difficult assessments to be made.

Suicides and mercy-killings will certainly continue to occur, and medical killing is believed by some to take place with alarming frequency. It should be noted that assertions regarding the levels of medical killing on both sides of the debate are probably worthy of some scepticism. This can make analysis of the extent of the

${ }^{106}$ G. Seay, "Can There Be a 'Duty to Die' without a Normative Theory?" (2002) 11 Cambridge Quarterly of Healthcare Ethics 266.

107 On money as a symbol, see J. Raz, The Morality of Freedom (Oxford 1986), ch. 13, especially at p. 350: "Money exchanges are the mark of liquidity, of easy, fast exchangeability. Because of this they are natural candidates for certain symbolic messages. But only those familiar with the conventions can understand their meaning". 
potential harm rather difficult. It is necessary to acknowledge that killing does happen in a medical sphere, but that while this remains unlawful it is not an option open to most people. There has been a (perhaps tentative) claim that annually 18000 thousand deaths a year in England and Wales could result from medically assisted dying. ${ }^{108}$ Equally startling is the seeming implied claim by Baroness Finlay and others that a want of evidence should lead us to infer that next to no medically assisted deaths take place. ${ }^{109}$ They are right to assert that one of the difficulties in understanding this problem is definitional: to non-consequentialists, ${ }^{110}$ morally relevant lines of intention can be drawn around certain conducts, and distinctions can be maintained between acts and omissions that are perceived as irrelevant by other commentators. Furthermore, whilst they endorse the doctrine of double effect, ${ }^{111}$ they point to widespread misapprehensions and misrepresentations made by nonmedics concerning the effect of opioids, and convey the general message that a reader should be cautious in crediting the figures extrapolated by non-clinicians. ${ }^{112}$ One basis of their claim is that the distinctions between act and omission, and between double effect and intentional killing, are clearer to clinicians. We suggest that perhaps this represents confusion between what is clear and what is credible, but their overall criticism is worthy of respect. It seems fair to submit that benevolent, consensual medical killing does occur, but that any effort to quantify its practice will lead to results that are in some way flawed. It is certainly not an option that is open to all who would benefit from it. Therefore, many will have to resort to suicide, mercy killing, or a continued but undesired existence.

The law generally falls in favour of advocating the prolongation of life, although there are limits placed on its power to interfere with suicidal decisions made by competent adults. There is no right in anyone to treat a condition - even a life threatening one-of a

${ }^{108}$ H. Biggs, "The Assisted Dying for the Terminally Ill Bill 2004: Will English Law Soon Allow Patients the Choice to Die?" (2005) 12 European Journal of Health Law 43, 51.

109 I.G. Finlay, V.J. Wheatley and C. Izdebski, "The House of Lords Select Committee on the Assisted Dying for the Terminally Ill Bill: Implications for Specialist Palliative Care" (2005) 19 Palliative Medicine 444, 446.

${ }^{110}$ Consequentialism, put simply, is the doctrine that measures the moral quality of an action by its effects, rather than, for example, the mental state or beliefs or desires of the actor. For a useful collection of essays on consequentialism, see S. Darwall (ed.), Consequentialism (Oxford 2003).

111 The doctrine of double effect allows a good means to be employed in pursuit of a good end, even if it will also result in a bad end, providing that the bad end is unintended, and that the overall harm is not disproportionate to the good end sought. Although some question the validity of the doctrine following the House of Lords decision in R. v. Woollin [1999] 1 A.C. 82 , it is still treated as good law and forms a part of good medical practice. For analysis of the doctrine see D. Price, "Euthanasia, Pain Relief and Double Effect" (1997) 17 Legal Studies 323 .

112 I. G. Finlay et al., note 109 above, at p. 446. 
person who refuses consent, regardless of that person's reasons. This is trite law, stated often within the courts, although its basis has been called into question. ${ }^{113}$ It is somewhat disingenuous to suppose that all deaths that result from a refusal of treatment are not suicidal, ${ }^{114}$ but the law is clear that a doctor who complies with his patient's wish is not complicit in a suicide. ${ }^{15}$ This principle extends to, for example, a family member who has assumed the role of a carer and would thus be liable to be prosecuted for wrongful omissions. ${ }^{116}$ The law will not (officially) condone, however, a medically assisted death by commission with the mens rea of murder, even if the patient consents. ${ }^{117}$ As with a suicide, this will have no financial ramifications for the deceased's next of kin, but the practice is unlawful and therefore not something that will be offered to many patients, or given to many who ask for it. What our policy-makers need to ask themselves-as a general question, but one that should have been made all the more pressing as a result of clause 10 of Lord Joffe's Bill-is should mercy killings entail a financial disincentive that does not enter the equation for suicide and physician-assisted dying? There are good arguments for both sides here, and the final answer would most appropriately be given by Parliament rather than the courts. The present answer, we suggest, is not the product of considered debate, but the result of variously developed policies.

\section{B. The Result for the Economically Rational Suicide}

Let us consider, then, the economically rational suicide. Suicide's decriminalisation means that there should be no punishment for a suicide either through the confiscation of his property, or through measures that would be punitive to his family. It follows that there may be financial incentives for a person considering the interests of his family to kill himself on the basis of factors such as those highlighted by Hardwig. The law as it stands urges him not to involve members of his family, as their complicity opens them to the risk of loss. But not everybody is in a position in which he can kill himself alone. Cases such as that of Dianne Pretty ${ }^{118}$ present

113 J. Keown, "Restoring Moral and Intellectual Shape to the Law after Bland" (1997) 113 L.Q.R. 482.

114 J. Keown and L. Gormally, "Human Dignity, Autonomy and Mentally Incapacitated Patients: A Critique of Who Decides?" (1999), http://webjcli.ncl.ac.uk/1999/issue4/ keown4.html.

115 Airedale NHS Trust v. Bland [1993] A.C. 789, 864 per Lord Goff; see also Ms. B v. an NHS Hospital Trust [2002] 2 All E.R. 449.

116 R. Jenkins, "Woman 'Vindicated' for Letting Husband Take his own Life", The Times, 28 April 2005; I. Herbert, "Wife Acquitted of Failing to Prevent Husband's Suicide" The Independent, 28 April 2005.

117 R. v. Cox [1993] 1 Med. L. Rev. 232.

118 Pretty v. United Kingdom (2002) 35 E.H.R.R. 1. 
the problem of a competent individual whose physical disability makes suicide impossible. In these cases, the financial disincentives of assistance currently have the potential to put people whose suffering is excruciating under some sort of "duty to live". ${ }^{119}$ Lord Joffe's Bill, if enacted, would have provided an alternative for someone in such a situation, but not somebody whose suffering resulted from a chronic illness that would not (be deemed to) kill him within six months.

Is this right? The argument needs to be had. We see in the Oregon Statute a whole raft of factors that the legislator considered should not be taken into account by a person assessing the value of continued existence. If we want to limit or remove financial incentives, surely we should either be consistent or able to justify the different ways of treating different cases. There may be good social or moral reasons for having policies that further deter the practice of mercy killings than the other types of killing. Given the complexity of many of the cases and the issues they raise, however, Parliament should give this explicit consideration. We suggest that in some circumstances it would be appropriate that the discretion afforded to the courts under the Forfeiture Act be extended to cases of murder. We would also like to hear in debate on any similar Assisted Dying Bill in the future the reasons for not allowing insurers the freedom of conscience that is afforded to all other parties. The duration of the debate on the earlier Bills did credit to the enormity of the issues they raised. It would be regrettable, however, if the issues we have discussed in this paper were not included in any future consideration just because they have not immediately struck protagonists as controversial.

\section{CONCLUSION}

This paper demonstrates that private law rules can play a considerable role in influencing end-of-life decisions. Even if no further legal developments take place, the existing principles direct the rationally suicidal to kill themselves, rather than seeking the assistance of others. Whilst we have focused on the current model for statutory intervention-Lord Joffe's Bill-these influences will need proper consideration when such a Bill is reintroduced. Policymakers are yet to make clear whether they intend money to be used

\footnotetext{
119 Rather like Hardwig, we use the term "duty" without providing a theoretical framework. It should be taken to reflect a person's feeling that he is bound, on his chosen means of assessment, not to allow a course of conduct in which his family members would have to take part; that all things considered, things are better if he lives, even if he would be better off dead. For an argument suggesting that the law creates in effect a duty to live, see W. Grey, "Right to Die or Duty to Live? The Problem of Euthanasia" (1999) 16 Journal of Applied Philosophy 19.
} 
as a vehicle for directing the rationally suicidal, and if so, in the particular manner that it currently operates.

Whatever else might be said, it is clear that clause 10 of the Assisted Dying for the Terminally Ill Bill 2005 deserved much greater attention than it received in Parliamentary scrutiny to date. It reinforces the pathways for consensual dying in favour of suicide and physician-assisted death, and away from mercy killings. Whilst this may be desirable, the absence of debate and explanation suggests that it is an accidental side effect of the clause and not its prime objective. What little evidence exists suggests that the clause was incorporated, not to meet the concerns of English law, but to reflect the state of affairs under the Oregon statute. Given the vast differences between English and US insurance law and practice, such a transplant is highly undesirable, and may kill the patient.

Even if some form of regulation of the relationship between life insurance and physician-assisted suicide is desirable, it is highly questionable that blanket statutory prohibitions are the most appropriate form of control. The matter could have been left to the insurance industry. The development of mixed products, providing both living and death benefits is within the gift of the industry. ${ }^{120}$ The costs of developing new products could be offset by minor changes to the taxation of such insurance products, if deemed to be in the wider general interest. If a greater degree of State control were required, the matter could be put in the hands of the "superregulator" of financial services, the Financial Services Authority. The adoption of agreed codes of practice would ensure that life insurance cover were not withdrawn routinely for patients seeking physician-assisted deaths, although insurers would be left to adopt a contrary position where their declared policy objectives conflicted with such cover.

The current situation is perverse. In a Bill that sought to enshrine autonomy, insurers were denied moral and market freedoms. In proposed legislation that received many hours of statutory debate, nobody explained the rationale behind a key clause. The danger of ad hoc reform without analytical discussion or the advancement of justifications is that the law will be unsuccessful. If insurers are not convinced of the need to continue to offer life insurance to those who suffer certain terminal illnesses, they can simply withdraw such cover from the market, and clause 10 (and its ilk) will do nothing to stop them. ${ }^{121}$

${ }^{120}$ See F. Parker, H. Rubin and W. Winslade, "Life Insurance, Living Benefits and Physicianassisted Death" (2004) 22 Behav. Sci. Law 615.

${ }^{121}$ See note 88 above on the limits of cl. 10. 
In conclusion, clause 10 is not just unnecessary, it is harmful. The Assisted Dying for the Terminally Ill Bill would have been much improved if, like the briefing notes, it had skipped the clause altogether.

\section{CAMBRIDGE JOURNALS}

